\title{
THE EXTENSION OF UK MEMBERSHIP IN THE EU: CAUSES AND CONSEQUENCES
}

\author{
Federico Fabbrini* \& Rebecca Schmidt ${ }^{* *}$
}

Article 5o(3) TEU foresees that a Member State which has notified its intention to withdraw from the EU will leave the EU two years after the notification, unless the European Council, in agreement with the Member State concerned, unanimously decides to extend this period. In March and April 2019, based on a request by the UK Government, the European Council twice granted an extension under Article 5o(3) TEU, postponing Brexit. This article offers a comprehensive analysis of the legal, political and institutional aspects of the most recent extension of the Brexit withdrawal period. For this purpose, it first provides an overview of the law of extension and in particular the relationship between extension, transition and revocation. Subsequently, it analyzes the politics of extension, explaining the reasons that pushed the UK to request it in spring 2019, and the conditions that the European Council attached to its decision allowing extension. Finally, the articles discusses the consequences of an extension on EU institutions, particularly the European Parliament, as well as on the functioning of the EU.

Keywords: Brexit, United Kingdom, European Union, Extension, Law, Politics

\section{TABLE OF CONTENTS}

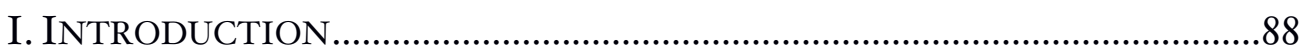

II. THE LAW OF EXTENSION....................................................................... 9I

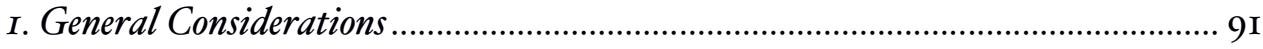

2. Comparing Extension to Transition and Revocation …………………………...... 93

III. THE POLITICS OF EXTENSION ……………………………………........ 96

IV. THE INSTITUTIONAL CONSEQUENCES OF THE EXTENSION ............... IO

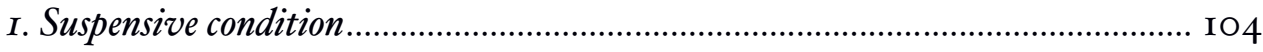

* Full Professor of EU Law at Dublin City University (DCU) and Founding Director of the DCU Brexit Institute.

** Assistant Professor of International Law at Dublin City University (DCU). 


\section{INTRODUCTION}

Leaving the European Union (EU) is easier said than done - as the United Kingdom (UK) realized in the Brexit process. Article 5O(3) Treaty on the EU (TEU) states that,

The Treaties shall cease to apply to the [withdrawing Member State] from the date of entry into force of the withdrawal agreement or, failing that, two years after the notification referred to in paragraph 2, unless the European Council, in agreement with the Member State concerned, unanimously decides to extend this period. ${ }^{\mathrm{I}}$

The last sentence of the abovementioned provision allows postponing the exit date of a Member State which has notified its intention to leave the EU under Article 5O(I) TEU, extending its membership of the EU beyond the two-year period triggered by the notification of withdrawal. Extension is decided by the European Council acting unanimously, and with the agreement of the withdrawing Member State.

Even though Article 5O(3) TEU explicitly foresees the possibility to postpone the exit date, a triggering of this provision appeared as beyond the realm of possibility for most of the Brexit negotiating process. When on 29 March 2017 the UK notified its intention to withdraw from the EU, then Prime Minister Theresa May clearly indicated that her country would leave the EU

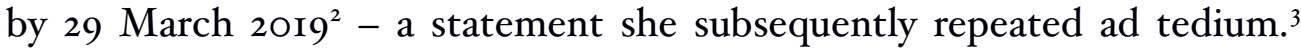
However, in spring 2019 - faced with the reality of the draft withdrawal agreement being voted down three times by the UK Parliament, and conscious of the gigantic problems that a disorderly, no-deal Brexit would

Emphasis added.

2 Prime Minister Theresa May, Letter to European Council President Donald Tusk, 29 March 2017; and United Kingdom notification under Article 50 TEU, XT 2000I/17, 29 March 2017

3 See, for instance, 'May - We are leaving the EU on March 29' Reuters (I6 January 2019) <https://www.reuters.com/article/uk-britain-eu-may-article5o/may-we-areleaving-the-eu-on-march-29-idUSKCNIPAIMo> accessed 23 August 2019. 
create to the national economy - the UK Prime Minister was forced to request twice an extension of $\mathrm{UK}$ membership in the EU, ${ }^{4}$ postponing Brexit to 3 I October 2019.

The purpose of this article is to analyze from a law and politics perspective the mechanism of extension, discussing also its short and long-term implications for the functioning of the EU. As the article claims, extension paradoxically confirms a contrario the resilience of the EU project, by revealing how difficult it is for a Member State to disentangle itself from one of the most successful systems of regional integration, without undermining its economy and unsettling its politics. At the same time, as the article points out, the extension of EU membership of a withdrawing Member State also creates new challenges for the EU itself. Because, contrary to what would happen in a transition period, in an extension period a withdrawing state maintains the rights and obligations of an EU Member State, the postponement of Brexit directly affected all the other 27 EU Member States (EU27), posing novel institutional challenges.

In particular, the article explains that the extension of the UK's membership of the EU had both short and long-term effects. On the one hand, in the short run, the postponement of Brexit created complications for the European Parliament (EP), as the UK had to participate in the elections for the $9^{\text {th }} \mathrm{EP}$ on 23 May 2019. However, because seats for the EP $2019-2024$ had been reallocated among the $\mathrm{EU}_{27}$, extension implied that the EP composition had to be re-adapted last minute to include $73 \mathrm{UK}$-elected members of the EP (MEPs). This put on hold 27 seats that had in the meanwhile been redistributed to other ${ }_{4}$ Member States - a situation likely to create litigation, since the $73 \mathrm{UK}$ MEPs are supposed to leave after Brexit, while the new MEPs remain on hold. On the other hand, in the longer term, the extension of $\mathrm{UK}$ membership in the EU also forced the $\mathrm{EU}_{27}$ to deal with the new scenario of a withdrawing state which remains part of the EU, becoming a potential nuisance in the functioning of the EU.

4 Prime Minister Theresa May, Letter to European Council President Donald Tusk, 20 March 20I9; and Prime Minister Theresa May, Letter to European Council President Donald Tusk, 5 April 2019. 
As the article suggests, therefore, the experience of the Brexit extension raises important lessons on the process of negotiating a withdrawal from the $\mathrm{EU}$, as well as on the organization of the EU itself. If the postponement of Brexit is a boost for the irreversibility of the project of European integration, it is also a challenge for the EU, as a free Union of free states. If a Member State were to feel caged into the EU against its will, it could become a nuisance in the functioning of the EU itself. In fact, this risk quite quickly revealed itself with Brexit, as immediately following the second UK request for extending Article 50, leading Euroskeptic member of the UK Parliament Jacob Rees-Mogg called for the UK to become 'as difficult as possible', using the veto and other tricks to obstruct and oppose the EU from within. ${ }^{5}$ While the European Council sought to minimize this threat by calling on the UK to abide by the principle of sincere cooperation, it remains to be seen whether this will have any effect. In this context, therefore, the article concludes that it is in the EU's interest to draw lessons from the Brexit extension to reorganize its constitutional setup in such a way that Member States which are laggards in the process of integration do not interfere with the ambitions of others.

As such, the article is structured as follows. Section II analyses in legal terms the characteristics of extension, as regulated by the TEU - explaining its difference from both transition and revocation. Section III overviews the practical application of Article 50(3) TEU in spring 2019, explaining the political and economic reasons that led the UK on 20 March and Io April 2019 to ask for an extension, and the institutional conditions that the European Council set in accepting the UK's requests. Section IV then considers the short-term implications of the Brexit extension, focusing on the changes and challenges this posed on the composition of the $9^{\text {th }}$ EP. Section V, in contrast, discusses the long-term implications of the Brexit extension, reflecting on how this forces the EU27 to adapt its internal way of operation. It also considers how the EU can minimize the potential disruption posed by ongoing UK membership, including the effect this may have for differentiated integration in Europe's future.

See tweet by Jacob Rees-Moog stating: 'If a long extension leaves us stuck in the EU we should be as difficult as possible....' @Jacob_Rees_Mogg (Twitter, 5 April 2019). 


\section{THE LAW OF EXTENSION}

\section{General Considerations}

Article 50 TEU establishes a three-step process by which a Member State can leave the EU in an orderly fashion. These are: first, the notification to the European Council outlining the intention to withdraw; second, the negotiation and conclusion of an agreement with arrangements regarding the withdrawal, taking into account the future relationship between the state and the Union; and finally the actual withdrawal. ${ }^{6}$ If after two years since the notification of the intention to leave the EU the withdrawing state and the EU have not concluded a withdrawal agreement, the withdrawing state could leave without an agreement. If however both the withdrawing state and the EU want to avoid a scenario of a disorderly exit, it is possible for the European Council, acting unanimously, and in agreement with the withdrawing state, to extend membership - postponing the exit date. ${ }^{7}$

6 Paul Craig, 'How Brexit will be Carried out? The Process of Withdrawal' in Federico Fabbrini (ed), The Law and Politics of Brexit (Oxford University Press 2017) 49.

7 The issue of extension has so far received limited in-depth analysis in scholarship. See Steve Peers, 'Trick or Treaty? The legal issues of the second extension of the UK's EU membership', EU Law Analysis (IO April 2019) $<$ http://eulawanalysis.blogspot.com/2019/o4/trick-or-treaty-legal-issues-of second .html> accessed 23 August 2019; Oliver Patel and Clément Leroy, 'Extending Article 50: Legal and Political Considerations' UCL European Institute, Brexit Insights Series (I5 March 2019) <https://www.ucl.ac.uk/europeaninstitute/sites/european-institute/files/article_5o_extension_paper_final_o.pdf> accessed 23 August 20 19; Sam Fowles, 'Extending Article 50: Key Legal Issues' LSE Brexit Blog (2O March 2OI9) <https://blogs.lse.ac.uk/brexit/2OI9/o3/2o/extendingarticle-50-the-key-legal-issues/ $>$ accessed 23 August 2019. For a more general analysis of withdrawal, including references to the possibility of extension see Christophe Hillion, 'Withdrawal under Article 50 TEU: An integration-friendly process' (2018) 55 Common Market Law Review 29-56; Piet Eeckhout and Eleni Frantziou, 'Brexit and Article 50 TEU: A Constitutionalist Reading' (2017) 54 Common Market Law Review 695-733; EU Parliament Briefing, 'Article 50 TEU: Withdrawal of a Member State from the EU' (February 2016) $<$ https://www.europarl.europa.eu/RegData/etudes/BRIE/20I6/57797I/EPRS_BRI (2016)577971_EN.pdf $>$ accessed 23 August 2019. 
Extension is an option explicitly foreseen by Article 50(3) TEU. However, this Article only provides a fairly rudimentary framework, and, for instance, does not clearly indicate the possible purposes of an extension. In fact, the provision only sets out a number of procedural requirements to trigger the extension of the withdrawal period by stating that '[...] the European Council, in agreement with the Member State concerned, unanimously decides to extend this period.'

As can be seen, Article 50(3) TEU describes extension in purely procedural terms. In particular, an extension of the withdrawal period can occur, provided that: I) the European Council makes a unanimous decision and 2) that the concerned Member State agrees. This raises a number of questions regarding the specific nature of the extension foreseen in Article 50 (3) TEU. The first concerns the relationship between the European Council and the withdrawing state in the exercise of granting the extension. So far, in the case of Brexit, it was the withdrawing state which requested the extension. ${ }^{8}$ However, the language of Article 50 TEU does not require that the withdrawing state makes such an application. In fact, albeit less likely, it seems possible that a decision to extend may be initiated also by the EU. What is, however, necessary in both cases is the unanimity of the European Council and the agreement by the Member State concerned. Therefore, an extension can never be put in place unilaterally but requires that all parties approve it.

Article 5O(3) TEU is instead silent on the substantive regulation of extension. However, once an extension is decided, the Member State which has notified its intention to leave the EU remains a Member State, with full rights and obligations. Yet, since that Member State is still on its way out of the EU, and therefore finds itself in the special situation foreseen by Article 5O(4) TEU, it seems conceivable that the European Council may introduce conditions that apply to an extension. In fact, it must be emphasized that according to Article 5O(3) TEU the European Council is under no obligation to grant the extension. In light of this, it appears justified for the European Council to make an extension dependent on conditions. However, a relevant legal

See Prime Minister Theresa May, Letter to European Council President Donald Tusk, 20 March 2019 and Prime Minister Theresa May, Letter to European Council President Donald Tusk, 5 April 2019. 
question is how far-reaching such conditions can be. Since the withdrawing state is still a Member State during the extension, it seems clear that the European Council cannot impose conditions that would go against the letter and the spirit of the EU treaties. For instance, if during an extension period the European Council were to ask the withdrawing Member State to apply rules from which it is exempted under the treaties, this would likely violate EU law. In fact, the conditions that the European Council may set during extension would still have to be consistent with the duty of sincere cooperation enshrined in Article 4(3) TEU. ${ }^{9}$

In summary, Article 50(3) TEU does not provide any rules regarding the specific arrangement of the extension. The Treaty only introduces a procedural requirement that extension be approved unanimously by the European Council in agreement with the withdrawing Member State. Instead it leaves open to the former the possibility to introduce conditions on extension, provided these are not incompatible with the EU treaties.

\section{Comparing Extension to Transition and Revocation}

From this viewpoint, extension differs from transition on the one hand, and revocation on the other. The Withdrawal Agreement concluded on I4 November $2018,{ }^{10}$ and the accompanying political declaration setting out the framework for the future relationship between the EU and the UK, ${ }^{\text {II }}$ crucially put in place a so-called transition period which is intended to lead to the conclusion of a future trade agreement. ${ }^{12}$ The transition - or in UK parlance: implementation - period was conceived as a time-limited devise which would allow the UK, after leaving the EU to maintain some privileges of EU

9 Article 4(3) TEU: 'Pursuant to the principle of sincere cooperation, the Union and the Member States shall, in full mutual respect, assist each other in carrying out tasks which flow from the Treaties.'

Io See Draft Agreement on the withdrawal of the United Kingdom of Great Britain and Northern Ireland from the European Union and the European Atomic Energy Community, as agreed at negotiators' level on I4 November 2018 (I4 November 2018) TF50 (2018) 55 .

II See Political declaration setting out the framework for the future relationship between the European Union and the United Kingdom (22 November 2018) XT $21095 / 18$.

I2 Draft Agreement (n I0) Arts I26 - I32. 
membership, including access to the internal market and customs union, in exchange for respect of EU laws and contributions to the EU budget. The focus here will be on how the transition period differs from the extension period.

A transition period is not a legal requirement set out in Article 50 TEU but, in the case of Brexit, was put into the withdrawal agreement for practical considerations. In the case of the UK-EU agreement the transition period would have been set for an initial period until 3I December 2020, but with the possibility to extend it once further till December 2022. During the transition period the UK will no longer be an EU Member State, and as such will not be participating in the EU institutions. However, the UK would continue to be part of the EU customs union and the single market, ${ }^{13}$ and EU legislation, rules and court decisions would apply to the UK as to any other EU Member State. ${ }^{14}$ Furthermore, the jurisdiction of the ECJ was to continue during this time, ${ }^{15}$ and the principle of supremacy and direct effect of EU law would also remain unchanged for this period. Importantly, the transition is more than just a timeframe to unwind existing relationships; rather it is designed to negotiate the actual post-withdrawal framework. As the outline political declaration concluded by the EU and UK in November 2019 is still fairly open regarding the future EU-UK relationship, both sides would need to use this period to arrive at an actual final agreement.

Compared to extension, a transition period comes with a number of similarities and one particular difference. In both circumstances Union law mostly applies and the UK remains bound by it. However, though being treated similar to a Member State for the time of the transition period, the $\mathrm{UK}$ is no longer a Member State. Membership would, in fact, require a renewed application under Article 49 TEU. Not being a Member State also means that the UK no longer participates in EU institutions. This is different in the context of an extension. The UK remains a Member State with full duties and rights of membership. Furthermore, as will be outlined below, it

13 Ibid Art 127 and Art 2a.

I4 European Commission, 'Fact Sheet Brexit Negotiations: What is in the Withdrawal Agreement' (I4 November 20I8) < http://europa.eu/rapid/pressrelease_MEMO-I8-6422_en.htm> accessed 23 August 2019.

15 Draft Agreement (n IO) Art I3I. 
continues to have the ability to unilaterally revoke its intention to withdraw, thus staying a full EU member without any additional requirements.

Whereas during the transition period the exiting state ceases to be an EU Member State but might be treated similarly to one in certain areas, the situation is very different in the case of a revocation. In this scenario the concerned state stays in the Union and continues to be a full Member State without any further plans of exiting.

Article 50 does not explicitly mention the revocation of the notification of withdrawal. The European Court of Justice (ECJ), however, ruled in Wightman that this is a possibility. ${ }^{16}$ The case was initiated by members of the UK Parliament, the Scottish Parliament and the EP before the Court of Session in Scotland. In their petition they asked whether Article 50 TEU can be unilaterally revoked by the UK with the result that the UK could remain in the EU. On 3 October 2018 the Court of Session referred the case to the ECJ. ${ }^{17}$ In its ruling in December 2018 the ECJ, following the advice of the Advocate General, ${ }^{18}$ held that the UK does have the option to unilaterally revoke its withdrawal notification. As reasons the ECJ stated that

the sovereign nature of the right of withdrawal enshrined in Article 5O(I) TEU supports the conclusion that the Member State concerned has the right to revoke the notification of its intention to withdraw from the European Union, for as long as a withdrawal agreement concluded between the European Union and that Member State has not entered into force or, if no such agreement has been concluded, for as long as the two-year period laid down in Article 5O(3) TEU, possibly extended in accordance with that provision, has not expired. ${ }^{19}$

Furthermore, the ECJ stressed that the option of revocation of the notification is also linked to the $3^{\text {th }}$ recital in the preamble to the TEU, the first recital in the preamble to the TFEU and Article I TEU regarding the creation of an ever closer Union; ${ }^{20}$ as well as the importance of the values of

16 Case C-62I/18 Wightman and Others EU:C:2018:999.

${ }_{17}$ Ibid para 9-I7.

18 Case C-621/18 Wightman and Others Opinion of Advocate General Campos SánchezBordona, delivered on December 42018 EU:C:2018:978, para I7O.

19 Case C-62I/18 Wightman and Others EU:C:2018:999, para 57.

20 Ibid para 6r. 
liberty and democracy as enshrined in the second and fourth recitals of the preamble to the TEU. ${ }^{21}$ According to the ECJ, an automatic end of membership after notification without the possibility to revoke that notification would amount to forced withdrawal of a Member State from the EU, if that state no longer wishes to exit. Such an outcome would be 'inconsistent with the Treaties' purpose of creating an ever closer union among the peoples of Europe'..$^{22}$ At the same time, the ECJ clarified that revocation had to be conducted in good faith, and that this required the withdrawing state to follow for revocation the same domestic constitutional procedure it had used to notify its intention to withdraw. ${ }^{23}$

If a Member State were to revoke its intention to leave the EU, according to the ECJ ruling the effect of this would be to return the state to its pre-Article 50 status, as a full Member State of the EU, with all rights and obligations. Revocation, in other words, would terminate the withdrawal process. In this it differs from extension, since during the latter the withdrawing Member State maintains all its rights and obligations of membership, but is also still a withdrawing state, since it has notified its intention to leave the EU - and as such is subject to a special status, resulting from Article 50(4) TEU.

In summary, extension constitutes a unique state where the withdrawing state remains a full Member State of the Union, with all rights and obligations (a difference from the transition period) and at the same time it also remains a withdrawing state, which still intends to end its EU membership (a difference from revocation). The unique circumstances of extension, therefore, create peculiar challenges, which will be discussed in the next section.

\section{THE POLITICS OF EXTENSION}

As mentioned, the European Commission Article 50 Task Force and the UK negotiators reached an agreement on a draft withdrawal treaty with an outline political declaration in November $2018 .{ }^{24}$ However, this agreement

\footnotetext{
21 $\quad$ Ibid para 62.

22 Ibid para 67.

23 Ibid para 75 .

24 Draft Agreement (n Io).
} 
was rejected by the UK Parliament on 15 January 2019 by a historic margin. ${ }^{25}$ Furthermore, despite additional reassurances made by the EU, ${ }^{26}$ Parliament also turned the agreement down in a second vote on 12 March $2019 .{ }^{27} \mathrm{~W}$ ith the exit date of 29 March 2019 approaching, and on the clear understanding that a no-deal Brexit would have dramatic consequences for the UK economy ${ }^{28}$ - not to mention the lack of preparation of the UK administrative state for a disorderly withdrawal ${ }^{29}$ - the option of extending Article 50 TEU suddenly became politically palatable in the UK.

As a result, on 20 March 2019 the UK Prime Minister requested a first extension of UK membership of the EU under Article 5O(3) TEU until 30 June 2019, with the aim to buy time to make another attempt at ratifying the withdrawal deal in Westminster. ${ }^{30}$ The European Council accepted the UK's request. However, aware of the legal and political difficulties that an extension would create on the approaching EP elections, ${ }^{31}$ the European

25 See House of Commons Exiting the European Union Committee, Response to the Vote on the Withdrawal Agreement and Political Declaration: Options for Parliament, HC i902, I6 January 2019.

26 See Instrument relating to the agreement on the withdrawal of the United Kingdom of Great Britain and Northern Ireland from the European Union and the European Atomic Energy Community, II March 2019, TF50 (2019) 61.

27 See House of Commons Exiting the European Union Committee, Response to the I2 March Vote on the Withdrawal Agreement and Political Declaration. Thirteenth Report of Session, HC 2073, 13 March 2019.

28 HM Government, 'HM Treasury analysis: the long-term economic impact of EU membership and the alternatives' (April 2016) <https://assets.publishing.service. gov.uk/government/uploads/system/uploads/attachment_data/file/517415/treasury _analysis_economic_impact_of_eu_membership_web.pdf> accessed 23 August 2019.

29 See National Audit Office, Contingency Preparations for Exiting the EU with No Deal, HC 2058, I2 March 2019; House of Commons Committee of Public Accounts, Brexit and the UK Border', HC 1942, I2 March 2019, 3 (stating that government 'departments have continued to struggle to prepare should the UK leave the EU without a deal' and reporting embarrassing cases of mismanagement of contingency preparations).

30 See Prime Minister Theresa May, Letter to European Council President Donald Tusk, 20 March 2019.

31 See European Commission President Jean-Claude Juncker, Letter to European Council President Donald Tusk, II March 2019 (stating that the UK exit 'should 
Council only granted an extension until I2 April 2019 (the last date by which the UK had to organize the holding of EP elections), unless the UK Parliament approved the withdrawal agreement before 29 March 2019. ${ }^{32}$ Yet, the UK Parliament rejected the deal a third time on 29 March 2019 - the day when the UK was originally expected to leave the EU. As a result, on 5 April 2019 the then Prime Minister Theresa May sent a letter to the European Council asking once again for an extension until 30 June $2019 .{ }^{33}$

On II April, the European Council again accepted the request, but rejected the UK timeframe and rather set a flexible deadline. ${ }^{34}$ Specifically, the European Council stated that:

Such an extension should last as long as necessary and, in any event, no longer than 3I October 2019. The European Council also recalls that, under Article 50(3) TEU, the Withdrawal Agreement may enter into force on an earlier date, should the Parties complete their respective ratification procedures before 3I October 2019. Consequently, the withdrawal should take place on the first day of the month following the completion of the ratification procedures or on I November 2019, whichever is the earliest. ${ }^{35}$

Moreover, the European Council clarified that the extension would end, with an automatic UK withdrawal on I June 2019 , if the UK was still a member of the EU on 23-26 May 20I9, had not ratified the Withdrawal Agreement by 22 May 2019, and had failed to hold elections to the EP. The European Council justified this, by stressing that extension

will have the consequence that the United Kingdom will remain a Member State until the new withdrawal date, with full rights and obligations in accordance with Article 50 TEU, and that the United Kingdom has a right

be complete before the European Parliament elections that will take place between 23-26 May [2019]. If the United Kingdom has not left the European Union by then, it will be legally required to hold these elections, in line with the rights and obligations of all Member States as set out in the Treaties').

32 European Council Decision (EU) 2019/476 taken in agreement with the United Kingdom of 22 March 2019 extending the period under Article 5O(3)TEU [2019] OJ $\mathrm{L} 8 \mathrm{O} \mathrm{I} / \mathrm{I}$.

33 See Prime Minister May, Letter to European Council President Donald Tusk, 5 April 20I9.

34 European Council Conclusions ro April 2019, EUCO XT 20015/19, paras 2 and 3.

35 Ibid para 9. 
to revoke its notification at any time. If the United Kingdom is still a Member State on 23-26 May 2019, and if it has not ratified the Withdrawal Agreement by 22 May 2019, it will be under an obligation to hold the elections to the European Parliament in accordance with Union law. In the event that those elections do not take place in the United Kingdom, the extension should cease on 3I May 2019. ${ }^{36}$

By so doing, the European Council effectively made extension conditional on the UK holding EP elections. Yet, as was outlined above, ${ }^{37}$ this is justified by the fact that the UK remains a member of the EU during the extension period, and as such is subject to EU obligations, including participating in EP elections. The European Council request is thus based on pre-existing obligations of the UK as a Member State rather than constituting a new condition imposed on the UK.

At the same time, the European Council stressed the UK's responsibility as a continuous Member State of the EU, clarifying that '[t]his further extension cannot be allowed to undermine the regular functioning of the Union and its institutions. ${ }^{38}$ In this regard, the European Council took note of the 'commitment by the United Kingdom to act in a constructive and responsible manner throughout the extension period in accordance with the duty of sincere cooperation' ${ }^{\prime 39}$ and stressed that it:

expects the United Kingdom to fulfil this commitment and Treaty obligation in a manner that reflects its situation as a withdrawing Member State. To this effect, the United Kingdom shall facilitate the achievement of the Union's tasks and shall refrain from any measure which could jeopardise the attainment of the Union's objectives, in particular when participating in the decision-making processes of the Union. ${ }^{4}$

Finally, the European Council also pointed out that where appropriate, the other 27 EU Member States 'will continue to meet separately at all levels to

\footnotetext{
36 Ibid para Io.

37 See above, section II.I.

38 European Council Conclusions EUCO XT 20015/19 (n 34) para Io.

39 Ibid.

40 Ibid.
} 
discuss matters related to the situation [of the EU] after the withdrawal of the United Kingdom.' ${ }^{4}$

This condition set out by the European Council makes clear, therefore, that extension is subject to the UK acting in good faith vis-à-vis the EU. The European Council is thus not adding any additional obligations or burdens, but seeks to affirm at the highest political level that the UK should not use the extension to disrupt the functioning of the EU. What the European Council is intending here is to prevent the extension period from being used as potential weapon to jeopardize from within the functioning of the EU institutions, perhaps as a strategy to leverage concession in the withdrawal process. That said, it remains to be seen whether that risk can be truly avoided: the obligation to act in good faith applies to the UK government in the European Council and the Council, but cannot be required for instance from individual UK-elected MEPs. Since the recent EU elections brought about a significant number of Eurosceptic MEPs, it is likely that their actions will not abstain from 'undermining the functioning of the Union and its institutions.'

As it is thus clear, the current extension does not only have consequences for the future of the withdrawal process and for UK internal political processes; it also affects the EU and its institutions. In fact, extension directly changes and challenges in significant and unprecedented ways also the composition of the EP, which is the focus of the next section.

\section{THE INSTITUTIONAL CONSEQUENCES OF THE EXTENSION}

The Brexit extension had significant consequences for the incoming $9^{\text {th }} \mathrm{EP}$ (2OI9-2O24)..$^{2}$ Pursuant to Article I4 TEU, the EP shall consist of a maximum of $75 \mathrm{I}$ members. EP seats are allocated among the Member States according to the principle of degressive proportionality, on the basis of European Council decision, adopted unanimously on a proposal by the EP and with its consent. On 28 June 20I8, the European Council had adopted a new decision

${ }^{4} \quad$ Ibid para 8.

42 See further Federico Fabbrini and Rebecca Schmidt, 'The Composition of the EP in Brexit Times' (2019) 44 European Law Review 710, from which this section draws. 
on the composition of the EP for the $9^{\text {th }} \mathrm{EP}$ term (2OI9-2024). ${ }^{43}$ Taking stock of the decision of the UK to leave the EU (and therefore, of the reduction of the total EU population), the European Council decided to lower the overall number of MEPs from 75 I to $705 .{ }^{44}$ At the same time, it decided to re-allocate 27 of the 73 seats previously assigned to the UK to I4 other EU Member States, in order to better fulfil the criteria of degressive proportionality, ${ }^{45}$ hence producing the re-allocation of seats described here.

43 European Council Decision (EU) 20I8/937 of 28 June 2018 establishing the composition of the European Parliament [2018] OJ L r65I.

44 An issue which goes beyond the remit of this article concerns instead the modalities of the elections of MEPs. On this see European Parliament legislative resolution of 4 July 2018 on the draft Council decision amending the Act concerning the election of the members of the European Parliament by direct universal suffrage, annexed to Council Decision $76 / 787 /$ ECSC, EEC, Euratom of 20 September 1976, P8_TA(2018)o282.

45 See also Leonard Besselink et al, 'The Impact of the UK's Withdrawal on the Institutional Set-up and Political Dynamics within the EU', study commissioned by the European Parliament Committee on Constitutional Affairs (April 2019). 


\begin{tabular}{|c|c|c|c|}
\hline Member State & MEPs 2014-20I9 & $\begin{array}{l}\text { MEP 2019-2024 } \\
\text { (after Brexit) }\end{array}$ & Variation \\
\hline Belgium & $2 I$ & $2 \mathrm{I}$ & \\
\hline Bulgaria & I7 & I7 & \\
\hline Czech Republic & $2 I$ & $2 \mathrm{I}$ & \\
\hline Denmark & I3 & I4 & $+\mathbf{I}$ \\
\hline Germany & 96 & 96 & \\
\hline Estonia & 6 & 7 & $+I$ \\
\hline Ireland & II & I3 & +2 \\
\hline Greece & $2 \mathrm{I}$ & $2 \mathrm{I}$ & \\
\hline Spain & 54 & 59 & +5 \\
\hline France & 74 & 79 & +5 \\
\hline Croatia & II & $\mathrm{I} 2$ & $+\mathbf{I}$ \\
\hline Italy & 73 & 76 & +3 \\
\hline Cyprus & 6 & 6 & \\
\hline Latvia & 8 & 8 & \\
\hline Lithuania & II & II & \\
\hline Luxembourg & 6 & 6 & \\
\hline Hungary & $2 \mathrm{I}$ & $2 \mathrm{I}$ & \\
\hline Malta & 6 & 6 & \\
\hline Netherlands & 26 & 29 & +3 \\
\hline Austria & I8 & I9 & $+\mathbf{I}$ \\
\hline Poland & $5 \mathrm{I}$ & $5^{2}$ & $+I$ \\
\hline Portugal & $2 \mathrm{I}$ & $2 \mathrm{I}$ & \\
\hline Romania & 32 & 33 & $+I$ \\
\hline Slovenia & 8 & 8 & \\
\hline Slovakia & $\mathrm{I} 3$ & I4 & $+\mathbf{I}$ \\
\hline Finland & $\mathrm{I} 3$ & $\mathrm{I} 4$ & $+\mathbf{I}$ \\
\hline Sweden & 20 & $2 \mathrm{I}$ & $+\mathbf{I}$ \\
\hline UK & 73 & $\mathrm{O}$ & -73 \\
\hline Total & $75 \mathrm{I}$ & 705 & \\
\hline
\end{tabular}

Nevertheless, the 2018 European Council decision on the new composition of the EP also envisioned a safeguard clause. In anticipation of a (possible, although then unlikely) scenario where the UK were to remain an EU 
Member State at the time of the May 2019 EP elections, Article 3(2) of European Council Decision (EU) 2018/937 stated that

in the event that the United Kingdom is still a Member State of the Union at the beginning of the 2019-2024 parliamentary term, the number of representatives in the European Parliament per Member State taking up office shall be the one provided for in Article 3 of the European Council Decision 2013/312/EU until the withdrawal of the United Kingdom from the Union becomes legally effective. ${ }^{46}$

Moreover, that same provision foresaw that, '[o]nce the United Kingdom's withdrawal from the Union becomes legally effective, the number of representatives in the European Parliament elected in each Member State shall be the one provided' by the new allocation criteria, with the consequence that:

All representatives in the European Parliament who fill the additional seats resulting from the difference between the number of seats allocated in the first and second subparagraphs shall take up their seats in the European Parliament at the same time. ${ }^{47}$

The Brexit extension therefore had significant consequences for the incoming $9^{\text {th }}$ EP (2019-2024). As was clearly requested by the European Council in granting the second extension, ${ }^{48}$ the $\mathrm{UK}$ had to participate in EP elections on 23 May 20I9. This required as a necessity to continue the old allocations of seats applied in the $8^{\text {th }} \mathrm{EP}$ term (2014-2OI9), ${ }^{49}$ scrapping at the last minute the new plan to re-allocate seats. This had two main consequences: on the one hand, the Brexit extension produced a suspensive condition for the extra 27 MEPs elected in I4 Member States; and on the other hand, it also produced a resolutive condition for the $73 \mathrm{UK}$-elected MEPs who joined the $9^{\text {th }}$ EP but are supposed to vacate their seats after Brexit has taken effect. Both of these situations raise novel legal issues.

\footnotetext{
${ }_{46}$ European Council Decision (EU) 20I8/937 (n 43) Art 3(2).

47 Ibid.

$4^{8}$ European Council Conclusions EUCO XT 20015/19 (n 34) para 3.

49 European Council Decision 2013/312/EU of 28 June 2013 establishing the composition of the European Parliament [2013] OJ L I8I, Art 3.
} 


\section{Suspensive condition}

There are 27 future MEPs who were not able to take up their mandate at the start of the new EP term on 2 July 2019, being held back from taking seats in the EP until the UK leaves the EU. This raises at least three distinct issues. First, how can the ex-post allocation be organized from a logistical point of view? Second, is it possible from a constitutional law perspective to elect MEPs based on a suspensive condition, or is this at odds with the rights of their mandates? And finally, and related to the last point, is such conditional election in line with the constitutional requirements of the electoral process?

Concerning the first issue, the last-minute extension of the withdrawal period caused logistical challenges regarding the allocation of MEPs. However, some Member States had foreseen in their domestic legislation how to deal with the possibility that the UK could remain in the EU, and therefore that the extra EP seats assigned to the country pursuant to European Council Decision (EU) 20I8/937 could not be actually be put into action. Ireland's European Parliament Elections (Amendment) Act 2019, for instance, envisaged the scenario of a delayed Brexit and therefore included a clause that allows limiting the accession of the extra MEPs to the EP until the Brexit issue is resolved. ${ }^{\circ}$ Section 6 of the 2019 Act provided that the newly elected extra MEPs 'shall not take up their seats in the European Parliament until such time as a date has been specified by the Parliament for the taking up of such seats. ${ }^{51}$

Moreover, other Member States adopted last minute, ad hoc legislative measures to deal with the UK's continuing membership and its impact on the forthcoming EP elections. For instance, France approved a special statute on 22 May 2019 - four days before the EP elections - which temporarily put on hold the five additional seats that France would have received according to the new composition of the EP..$^{2}$ Similar provisions were made in other Member States affected by European Council Decision (EU) 2018/937,

5o See European Parliament Elections (Amendment) Act 2019.

5 I Ibid sec 6(j).

52 See Loi n ${ }^{\circ} 2019-487$ du 22 mai 2019 relative à l'entrée en fonction des représentants au Parlement européen élus en France aux élections de 2019, JORF nºII9 du 23 mai 2019. 
including Spain ${ }^{53}$ and Poland.54 There are, however, also Member States which did not adapt their national legislation. Yet, this does not necessary mean that these countries do not have a procedure in place to deal with the issue and will not able to allocate the additional seats at a later point in time. For instance, in Austria, which uses an electoral system of proportional representation $(\mathrm{PR})$ with the application of the d'Hondt system to return seats, together with the option to name or rank individual candidates from the party list, a ranking will clearly establish which candidate can enter the EP. 55 While it remains to be seen how smoothly such unprecedented procedures will run in the affected Member States once Brexit does materialize, the first, logistical issue appears to be manageable, despite its novelty.

A legally more complicated question is instead the second one - whether from a constitutional point of view a suspensive condition is at odds with the rights and privileges linked to the office of MEPs. However, here it is important to reiterate that the MEP status for the 27 representatives that will only join the EP after Brexit is conditional. Thus, they will only receive their

53 See Real Decreto 206/2019 (I de abril, 2019) (stating that '[d]e conformidad con el artićulo 3.2 de la Decision (UE) 2018/937 del Consejo Europeo, una vez sea juridicamente efectiva la salida del Reino Unido, los cinco nuevos escanõs que corresponden a Espanã serań asignados por la Junta Electoral Central a las candidaturas a las que puedan corresponder como consecuencia de la aplicación de las reglas establecidas en el artićulo 216 de la Ley Orgańica 5/1985, de I9 de junio, a los resultados del proceso electoral celebrado el 26 de mayo de 2019, sin que sea necesario realizar nuevas elecciones.')

54 See Law of 4 April 2019 establishing principles of the order of filling in the mandates of the deputies for the European Parliament elected by Poland for 20192024 term (Dz.U. 2019 poz 708) (foreseeing that, applying existing provisions of the Electoral Code, the National Electoral Commission indicates which electoral committee received 52nd quotient. In the next step, the National Electoral Commission checks which MEP elected from the list of that committee received the lowest number of votes). Since Art $329 \$$ I of the Electoral Code states that Poland elects as many MEP as indicated in EU law no further amendments were necessary.

55 See Bundesgesetz über die Wahl der Mitglieder des Europäischen Parlaments, \ 75 (Ermittlung des vorläufigen Wahlergebnisses durch die Bundeswahlbehörde) in combination with $\$ 77$ (Ermittlung der Mandate durch die Bundeswahlbehörde) and $\$ 78$ (Zuweisung der Mandate, Niederschrift, Verlautbarung). 
mandates if the suspensive condition - Brexit - occurs. French legislation in this regard is particularly explicit as it states that '[c]es candidats prennent leur fonction de représentants au Parlement européen à compter de la date du retrait du Royaume-Uni de l'Union européenne. ${ }^{56}$ This point was further clarified in the press release of the Council of Ministers which approved the emergency legislation as meaning that 'tant qu'ils n'entrent pas effectivement en fonction, les droits et obligations attachés à la qualité de représentants au Parlement européen ne leur sont pas opposables, notamment en matière d'incompatibilités. ${ }^{57}$

It is important to note that all legislatures foresee the possibility of members joining at a later stage in the case that the originally elected representative is no longer able to fulfil his or her mandate. ${ }^{8}$ There is, however, a qualitative difference between such a procedure and the case at hand. Substitute candidates are not elected but are simply on a substitute list. The 27 future MEPs under discussion here are instead elected, even though they can only take up their seats at a later stage of the parliamentary period. Given the nature of a suspensive condition, and the uncertainty around the UK's withdrawal from the EU, this later stage might never even materialize. Nonetheless, given that these MEPs in waiting have not taken up their mandate they have not yet attained the rights and privileges linked to it. Consequently, the suspensive condition does not violate constitutionally protected rights linked to the status of MEP.

Related to these considerations is the third issue, which concerns the effects of a suspensive condition on the representational system. The 2019 EP elections provide the novelty of a partially conditional election. The materialization of the people's vote will depend on an outside factor - Brexit. To the best of our knowledge, there has not been any precedent for such an approach and it is unclear whether this procedure has any impact on the

${ }_{56}$ See Loi n $2019-487$ du 22 mai 2019 relative à l'entrée en fonction des représentants au Parlement européen élus en France aux élections de 2019, JORF nºIr9 du 23 mai 2019, Art. unique.

57 'Compte rendu du Conseil des ministers du 24 avril 2019' $<$ https://www.gouvernement.fr/conseil-des-ministres/2019-04-24/entree-enfonctions-des-representants-au-parlement-europeen > accessed 23 August 2019.

58 See for instance Legge 24 gennaio I979, n. I8 Elezione dei membri del Parlamento europeo spettanti all'Italia, G.U. n. 29 del 30 gennaio 1979, Art 6. 
credibility and the trust in the electoral system. If an elected candidate is not able to take up her office due to ongoing political negotiations about Brexit, her electorate might consider their vote to be cast in vain. This might cause doubts on the democratic nature of the elections and in turn of the Union, which is clearly envisaged in Article 13 TEU. However, the recent elections indicate that such fears are unfounded. Rather than doubt and suspicion about democratic representation within the Union, the May 2019 EP elections saw the highest participation in the history of the Union. Thus, it appears that, among other factors, the ongoing political debates about Brexit revitalized democratic processes within the Union rather than stifling them. ${ }^{59}$

In sum, it seems that the issues arising from the suspensive effects of a prolonged Brexit are in line with broader EU constitutional law requirements. The EU and its Member States have taken legislative measures to regulate the problem. As a result, this procedure, albeit novel, will be based on legal grounds. Furthermore, the 27 MEPs which would have been elected had it not been because of a Brexit extension, will not take up their mandate until after the UK withdraws from the EU. Thus, they will not be bestowed with any official right or obligations; and the Brexit condition will therefore not interfere with any prerogatives linked to the mandate.

\section{Resolutive condition}

More problematic about the current arrangement is the situation of the 73 MEPs which were elected in the UK. According to the European Council Decision, these MEPs are supposed to leave the EP after Brexit has materialized. ${ }^{60}$ Article 3(2) of European Council Decision 2018/937 seems to consider this almost a technicality, by envisaging a termination of the UK mandates and an automatic transition to the new EP composition-key.

59 See French President Emmanuel Macron, Letter, 4 March 20I9, available at: https://www.elysee.fr/es/emmanuel-macron/2019/03/o4/pour-une-renaissanceeuropeenne.fr accessed I3 September 2019 (citing Brexit as a reason to participate to EU elections).

60 European Council Decision (EU) 2018/937 (n 43), Art 3(2). European Council Decision (EU) 2019/584 taken in agreement with the United Kingdom of II April 2019 extending the period under Article 5O(3) TEU [2019] OJ L IOI, recital II. 
However, here the question arises whether, and under what conditions, these MEPs can be required to give up their seats and leave the EP before the termination of their regular term of office. Unlike the MEPs on the "waiting lists" discussed above, these 73 MEPs have fully taken their office with the elections on 23 May 2019. Thus, at the time when they are supposed to leave the EP they have a valid mandate and fully enjoy the rights and privileges that come with the status of being a MEP. The fact that Brexit could have a resolutive effect on the mandate of UK-elected MEPs raises profound constitutional questions.

A series of arguments are mentioned to support this conclusion. First, from the perspective of classic public international law, a Member State's withdrawal from a treaty entails exit by its representatives from all the treaty institutions. ${ }^{6 r}$ Second, from the perspective of administrative law, Brexit deprives UK-elected MEPs of the citizenship requirements to serve within the EU institutions. ${ }^{62}$ And third, from the perspective of democratic theory, it may seem unfair for UK-elected MEPs to take decisions that affect EU citizens after the UK is no longer an EU Member State. ${ }^{63}$

Yet, none of these arguments seem to withstand careful scrutiny. First, the ECJ has repeatedly argued that the EU constitutes a new legal order, ${ }^{64}$ and that EU constitutional law rather than public international law governs its functioning. ${ }^{65}$ Second, the administrative view seems to clash with the fact that not only UK citizens can be elected as MEPs in the UK; in fact, EU law entitles EU citizens to run in EP elections in the $\mathrm{UK},{ }^{66}$ and $\mathrm{UK}$ electoral law

6r See Vienna Convention on the Law of the Treaties, II55 UNTS 331, Art 70.

${ }_{62}$ See also Herwig CH Hoffmann, 'The impact of Brexit on the legal status of European Union officials and other servants of British nationality', study commissioned by the European Parliament Committee on Constitutional Affairs (December 20I7).

63 See Robert A Dahl, On Democracy (Yale University Press 1998) 78 (explaining that democracy is based on the principle of affected interests, whereby people vote on matters that affect them).

64 Case C-26/62, Van Gend en Loos EU:C:I963:I.

65 Case C-621/18 Wightman and Others EU:C:2018:999.

66 See Charter of Fundamental Rights of the European Union, Art 39 ('I. Every citizen of the Union has the right to vote and to stand as a candidate at elections to the 
extends the passive suffrage even to non-EU citizens. ${ }^{67}$ As a result, there is a handful of MEPs elected in the UK on 23 May 2019 who are either dual nationals or actually not British citizens at all. ${ }^{68}$ Clearly, Brexit would not remove the EU citizenship requirement to hold office (at least for them). Third, the democratic argument disregards the fact that already today UKelected MEPs were fully involved within the EP even in deciding matters for example on the governance of the Eurozone, or Schengen - to which the UK was not actually participating in, due to its various opt-outs from key areas of European integration. ${ }^{69}$

In fact, there are strong constitutional arguments why the $73 \mathrm{UK}$-elected MEPs cannot be forced to leave their seats after Brexit. ${ }^{\circ}$ Whereas the old text of Article I89 TEC stated that the EP represented 'the peoples of the States brought together in the Community', Article I4(2) TEU proclaims that the 'European Parliament shall be composed of representatives of Union citizens', and Article I4(3) states that 'members of the European Parliament shall be elected for a term of five years.' As a result, the EP today is an institution which represents EU citizens, and not citizens of the EU Member

European Parliament in the Member State in which he or she resides, under the same conditions as nationals of that State.')

${ }_{67}$ See European Parliament Elections Act 2002, sec. Io(3A). See also Case C-I45/O4 Spain v. United Kingdom EU:C:2006:543 (upholding the UK legislation extending the franchise for EP elections to third-country nationals who are Commonwealth citizens residing in Gibraltar).

68 See also 'The Brexit Vote: Here are all the MEPs elected for Britain and Northern Ireland', The fournal (28 May 2019) <https://www.thejournal.ie/british-europeanvote-meps-brexit-4654763-May2019/> accessed 23 August 2019 (reporting the names of all the 73 MEPs elected in Great Britain and Norther Ireland, and indicating that among others Henrik Overgaard-Nielsen (Brexit Party) has dual British and Danish citizenship; Irina Von Wiese (Lib Dems) has British and German citizenship; Christian Allard (SNP) has British and French citizenship; and Martina Anderson (Sinn Fein) has only Irish (not British) citizenship).

69 See for a discussion of this problem: Deirdre Curtin and Cristina Fasone, 'Differentiated Representation: Is a Flexible European Parliament Desirable?' in Bruno De Witte et al (eds) Between Flexibility and Disintegration: The State of EU Law Today (Edward Elgar Publishing 2017).

70 Federico Fabbrini, 'The Institutional Consequences of a 'Hard Brexit", study commissioned by the European Parliament Committee on Constitutional Affairs (May 2018). 
States. This is evidenced by the fact that current members of the EP elected in the UK have been voted into office also by non-British EU citizens resident in the $\mathrm{UK}$ who exercised their voting rights for EP elections in accordance with Article 22(2) TFEU, Article 39 EU Charter of Fundamental Rights, and Directive 93/109/EC. ${ }^{71}$ In fact, contrary to what has occurred in the European Council and the Council since the notification of withdrawal, MEPs elected in the UK have not been excluded from Brexit-related deliberations and decisions within the EP.

In light of the above, it seems possible to claim that the constitutional principle of representative democracy codified in Article Io(2) TEU, according to which 'citizens are directly represented at Union level in the European Parliament', allows MEPs elected in the UK to serve their role for the full length of their five-year mandate..$^{2}$ Moreover, another institutional factor has to be accounted for in support of this conclusion. The new EP elects a new European Commission. Pursuant to Article i7(7) TEU the President of the European Commission 'shall be elected by the European Parliament by a majority of its component member'; the EP scrutinizes the candidates put forward by the Member States for the role of Commissioners; and ' $[\mathrm{t}] \mathrm{h}$ he President, the High Representative of the Union for Foreign Affairs and Security Policy and the other members of the Commission shall be subject as a body to a vote of consent by the European Parliament.' 73 The fact that the EP is constitutionally mandated to approve the formation of the new Commission means that a relation of confidence is developed between these two institutions. ${ }^{74}$ Modifying the composition of the EP in the course of its $9^{\text {th }}$ term, therefore, would unsettle the inter-institutional relation between the EP and the Commission, potentially affecting the confidence in the Commission itself.

${ }_{71}$ Council Directive 93/I09/EC of 6 December 1993 laying down detailed arrangements for the exercise of the right to vote and stand as a candidate in elections to the European Parliament for citizens of the Union residing in a Member State of which they are not nationals [1993] OJ 1993 L 329/34.

${ }_{72}$ See also Protocol (No 7) on the privileges and immunities of the European Union, Art 9.

$73 \quad$ Art $17(7)$ TEU.

74 See Editorial comments, 'After the European elections: Parliamentary games and gambles' (2014) 5I Common Market Law Review I047. 
In fact, an ex post change in the composition of the EP, with a departure after Brexit of 73 UK-elected MEPs - the third largest national delegation in the EP - would inevitably alter the political equilibria within the EP. This is particularly relevant in 2019 since the President-elect of the European Commission Ursula von der Leyen - who was nominated by the European Council on 2 July 2019, ${ }^{75}$ following a long wrangling between the heads of state and government, which led to the abandonment of the Spitzenkandidaten method $^{76}$ - was approved in her post by the EP on 16 July 2019 with a margin of only nine votes: 383 for, 327 against, with 22 blank and one annulled votes the required majority being 374 votes. ${ }^{77}$ As it quickly appeared, in securing President Von der Leyen's election, the votes of a number of UK-elected MEPs proved influential, including the ten Labour MEPs (who sit in the Socialists \& Democrats group), the four Conservative Party MEPs (who sit in the group of European Conservative and Reformists) and crucially the 16 Liberal Democrats (Lib-Dems) members of the newly created group Renew Europe. If, of course, such MEPs were to leave the EP after Brexit - although together with the 29 MEPs of the Brexit Party, who strongly opposed President Von der Leyen - this will affect the political equilibria within the EP, potentially depriving the European Commission of the mathematical majority on which it relies within the EP, and forcing a governmental crisis in the EU.

\section{CONCLUSION: BEYOND EXTENSION}

In conclusion, the Brexit extension created short-term changes and challenges to the functioning of the EP, which are likely to lead to litigation. As we explained, the suspensive condition that Brexit has on 27 MEPs seems to be legally acceptable, and practically manageable, since these individuals

75 See European Council Conclusions, 2 July 2019, EUCO I8/19.

${ }^{6}$ See European Council President Donald Tusk, statement, 28 May 2019 (indicating that 'there can be no automaticity' in the appointment of the European Commission President in light of EP election results).

77 See European Parliament, 'Press Release - European Parliament Elects Ursula von der Leyen as first Female Commission President' (I6 July 2019) $<$ http://www.europarl.europa.eu/news/en/press-room/201907IIIPR56824/ parliament-elects-ursula-von-der-leyen-as-first-female-commission-president> accessed 23 August 2019. 
do not actually acquire any prerogative as MEPs until a future point in time when the UK leaves the EU. Instead, profound constitutional questions would result from the resolutive condition. Constitutional arguments related to the nature of MEPs, and institutional considerations connected to the electoral relation between the EP and the Commission, suggest that UKelected MEPs cannot be forced to vacate their seats after Brexit, and before the end of their five-year mandate. Yet, as Article I4 TEU sets a fixed, maximum number of $75 \mathrm{I}$ MEPs, if the $73 \mathrm{UK}$-elected MEPs do not forfeit their seats after Brexit, it becomes impossible for the extra 27 MEPs that could be subsequently re-deployed from I4 other Member States to take up these seats. The adoption of a special protocol would therefore be required, as we suggested elsewhere. ${ }^{78}$

However, the Brexit extension has implications also for the other EU institutions. On I9 August 2019, the UK Government announced that it will stop attending most meetings of the Council of the EU as of I September 2019. ${ }^{79}$ As explained by the UK Secretary of State for Exiting the EU, Stephen Barclays, '[t]his will free up time for Ministers and their officials to get on with preparing for our departure on October 3I [20I9]. ${ }^{180}$ Nevertheless, the UK Government clarified that it will continue to attend meetings of the Council of the EU, 'where the UK has a significant national interest in the outcome of discussions $^{18 \mathrm{I}}$ - listing meetings on UK exit, sovereignty, international relations, security, or finance as examples. As such, while the UK Government indicated that this 'decision is not intended in any way to frustrate the functioning of the $\mathrm{EU}^{182}$ - and correspondingly arranged to delegate pursuant to Article 239 TFEU its voting rights to Finland, as the Member State holding the six-month presidency of the Council of the EU -

${ }_{78}$ See Fabbrini and Schmidt (n 42).

79 UK Government, 'Press release, UK officials will stop attending most EU meetings from I September' (20 August 20I9) <https://www.gov.uk/government/news/ukofficials-will-stop-attending-most-eu-meetings-from-I-september $>$ accessed 23 August 2019.

8o Ibid.

8 I Ibid.

82 Ibid. 
the move signaled a willingness to continuously leverage its involvement in the EU to protect its 'ongoing national interest. ${ }^{183}$

Moreover, on 23 August 2019, the UK Government also announced that it would not nominate a UK Commissioner for the $2019-2024$ term. ${ }^{8}$ Even though pursuant to Article 17(5) TEU, as amended by a decision of the European Council, the Commission shall consist of one national for each Member State, ${ }^{85}$ the UK refrained from nominating 'a UK Commissioner for the new Commission' in view of the intention of the new Prime Minister to leave the EU by 3I October 2019. ${ }^{86}$ As the UK Permanent Representative to the EU Sir Tim Barrows explained in a letter to the head of the transition team of the new European Commission President, this move is 'not intended to stop the EU appointing a new Commission, ${ }^{187}$ and the UK

will not object to the Council, in accordance with Article $17(7)$ [TEU] and in agreement with the President-elect, adopting the list of candidates for the appointment as members of the Commission and communicating that list to the European Parliament. ${ }^{88}$

As a result, by deciding unilaterally not to exercise its right to nominate a European Commissioner, and by choosing selectively whether to exercise its right to participate in EU Council meetings, the UK has been affecting the composition and decision-making process of other EU institutions.

$8_{3}$ Ibid.

${ }_{4}$ UK Government, 'Press Release, The UK will not nominate a new Commissioner to the EU' (23 August 2019) <https://www.gov.uk/government/news/the-uk-willnot-nominate-a-new-commissioner-to-the-eu> (accessed 29 August 2019).

85 See in fact European Council Decision 2013/272/EU of 22 May 2013 concerning the number of members of the European Commission, [2013] OJ L I65/98, Art I (stating that '[t]he Commission shall consist of a number of members [...] equal to the number of Member States'). Technically this sets a fixed number for the size of the college of Commissioner: 28 , so it remains to be seen how this can be squared if the UK extends further its EU membership without appointing a Commissioner.

86 Ambassador Sir Tim Barrow, 'Letter to the Head of Transition Team (European Commission President-elect) and the Secretary General of the Council of the European Union' (23 August 2019) <https://assets.publishing.service.gov.uk/ government/uploads/system/uploads/attachment_data/file/827315/Nomination_of _a_Commissioner_-_FINAL.pdf $>$ accessed 29 August 2019.

87 Ibid.

88 Ibid. 
Therefore, while still remaining during the extension period an EU Member State 'with full rights and obligations', ${ }^{89}$ the UK is carving out for itself a diminished membership status, with only partial involvement in the governance of the EU. Yet, this condition of semi-membership could drag on for a much longer time, raising important constitutional questions for Europe's long-term future. In fact, the new President of the European Commission, Ursula Von der Leyen, already indicated that she would be open to a further extension of UK membership. ${ }^{9 \circ}$ This scenario is likely given the constitutional crisis that has played out in the UK since Boris Johnson took over as Prime Minister.

Following the decision by Prime Minister Johnson on 28 August 2019 to prorogue Parliament, on 3 September 2019 Westminster voted to seize control of the parliamentary agenda. With an emergency motion it tabled for discussion a piece of legislation designed to take the risk of a hard Brexit off the table and impose on the PM the duty to seek with the EU a further extension under Article 50 TEU in case a deal had not been found. ${ }^{91}$ The bill, which was drafted by Labour MP Hillary Benn, the Chairman of the Brexit Select Committee, was approved at record speed on 4 September 2019, by a majority of 328 to $30 \mathrm{I}$, with the crucial vote of moderate Tory MPs. It specifically requires the UK Government to seek an extension until at least 3I January 202O, thus further proroguing the UK membership in the EU, to buy extra time to arrange an orderly exit and avert a no-deal.

However, the ongoing membership of a withdrawing Member State poses institutional issues for the future of the EU: the EU is a free Union of free states, all of which have willingly decided to share their sovereignty on a reciprocal basis to federate into a supranational organization. In fact, if a state were to feel caged into the EU against its will, this may challenge the constitutional compact on which the Union is based, and such state could become a nuisance in the functioning of the EU itself. We have already

89 See European Council Conclusions EUCO XT 20015/19 (n 34) para 6.

90 See European Commission President-elect Ursula von der Leyen, speech at the European Parliament, Strasbourg, I6 July 2019 (indicating that the withdrawal agreement cannot be renegotiated but that the Commission is willing to further extend UK membership of the EU in October 2019 if necessary).

9r $\quad$ European Union (Withdrawal) Act (No. 2) 2019. 
mentioned the threat of Jacob Rees Mogg, a leader of the pro-Brexit camp, to make the UK as difficult as possible during the extension period. ${ }^{92} \mathrm{~W}$ ith the recent appointment of Boris Johnson as the new UK Prime Minister, Rees Mogg has now become Leader of the House - that is the chief whip of the Tory majority in the House of Commons - and there is a risk that such strategy of undermining the Union from within may be put into action. ${ }^{93}$ If faced with further extensions such sentiments are likely to grow. Even though a UK government might not adopt such a subversive position outright, it will be pressured by these forces, as it has been before and throughout the Brexit process. Thus, it will likely oppose policies that, although highly beneficial for the EU itself, might be less so for a third state. And the longer the extension lasts the more likely it is that these problems will intensify.

It is precisely to avert this threat that the European Council in accepting the second extension requested the UK government to act in a constructive and responsible manner throughout the extension period in compliance with the Treaty-based duty of sincere cooperation. ${ }^{94}$ Yet, it is not clear whether this can be expected, and much less enforced - which raises the important question of whether the $\mathrm{EU}$ should in fact start thinking about more structural institutional solutions to accommodate different tiers of membership within its ranks. If two years of Brexit talks have proved the difficulties of leaving the EU, the 2016 Brexit referendum unearthed uneasiness with the EU that the Union would ignore at its own peril. And if the $\mathrm{UK}$ is due to remain in the EU for a while more, with Brexit postponed ad Kalendas Graecas, it is certainly in the EU's interest to reorganize its constitutional setup in such a way that states who are laggards in the process of integration do not interfere with the ambitions of others..$^{95}$

92 Tweet by Jacob Rees-Moog (n 5).

93 Alistair Smout, 'UK PM Johnson appoints Rees-Mogg as leader of the House of Commons' Reuters (24 July 2019) <https://www.reuters.com/article/us-britain-euleader-reesmogg/uk-pm-johnson-appoints-rees-mogg-as-leader-of-the-house-ofcommons-idUSKCNIUJ3I $\mathrm{I}>$ accessed 23 August 2019.

94 See European Council Conclusions EUCO XT 20015/19 (n 34) para 7.

95 See e.g. Ivan Krastev, After Europe (Penn Press 2017); George Soros, 'How to Save Europe' Project Syndacate (29 May 2018); and Sergio Fabbrini, Europe's Future (CUP 2019). 
In other words, the EU itself should promote constitutionally entrenched mechanisms of institutional differentiation where states with diverse visions of integration can coexist without undermining each other. The way for the EU to do so is to assume a clear constitutional differentiation between the internal market, on the one hand, and a political and economic union, on the other. ${ }^{96}$ Effectively, there are two Europes in the EU today - one political and economic in nature and another purely focused on market integration. These Europes have coexisted for many years, but Brexit has actually made their difference crystal clear. If the Brexit postponement is a boost for the irreversibility of the project of European integration, it is also a challenge for a free Union of free states. In this context, a treaty reform to differentiate tiers of membership and levels of commitments between Member States must emerge as an indispensable way forward.

96 See further Federico Fabbrini and Miguel Poiares Maduro, 'Is the EU Prepared if the UK Were to Stay?', EU News (Io January 20I9) <https:/www.eunews.it /2019/or/ro/eu-prepared-if-the-uk-were-to-stay-bremain/II2827> accessed 23 August 2019. 